\title{
МОТИВИРОВОЧНЫЕ ПРИЗНАКИ НОМИНАЦИИ ЛЕКАРСТВЕННЫХ РАСТЕНИЙ
}

\section{MOTIVATION CHARACTERISTICS OF NOMINATION MEDICINAL PLANTS \\ N. Hajiakhmedov \\ P. Aybatyrova \\ A. Hajiakhmedova}

Summary: The article considers the motivational features that formed the basis of the nomination of medicinal plants in the Kumyk language. The principles of nominating the names of many plants are based on somatic, topological-logical and functional motivational features. The taste qualities of plant fruits, their specific smell, and tactile signs also formed the basis for the motivation of pharmacophytonyms. Unproductive are the motivational signs of the "ethnonym", signs associated with related relationships and characteristics of the person. The study showed that in the Kumyk language there are quite a lot of names of medicinal plants created on the basis of the metaphorical nomination of flora, according to some models. The national-cultural features of the nomination of medicinal herbaceous plants reflect the anthropometric perception of the surrounding world.

Keywords: phytonym, pharmacophytonym, principles of nomination, motivation feature, Kumyk language.
Гаджиахмедов Нурмагомед Эльдерханович

Д.филол.н., профессор, Дагестанский государственный университет (2. Махачкала) nur1@yandex.ru

Айбатырова Пахай Казбековна аспирант, Дагестанский государственный университет (2. Махачкала) aybat13@yandex.ru

Гаджиахмедова Аида Нурмагомедовна

Первый Московский государственный медицинский университет имени И. М. Сеченова Министерства здравоохранения Российской Федерации (Сеченовский университет), (2. Москва) ajka13@mail.ru

Аннотация: В статье рассматриваются мотивировочные признаки, которые легли в основу номинации лекарственных растений, в кумыкском языке. В основе принципов номинации названий многих растений лежат соматический, топологический и функциональный мотивировочные признаки. Вкусовые качества плодов растений, их специфический запах, тактильные признаки также легли в основу мотивации фармакофитонимов. Непродуктивными являются мотивировочные признаки «этноним», признаки, связанные с родственными отношениями и особенностями характеристики человека. Исследование показало, что в кумыкском языке достаточно много названий лекарственных растений, созданных на основе метафорической номинации флоры, по разным моделям. Национально-культурные особенности номинации лекарственных травянистых растений отражают антропометричность восприятия окружающего мира.

Ключевые слова: фитоним, фармакофитоним, принципы номинации, мотивировочный признак, кумыкский язык.

настоящей статьи является приоритетным для сравнительных и сопоставительных исследований названий лекарственных растений в языках разных систем и особенно для их изучения в тюркских языках.

Актуальность исследования обусловлено не только отсутствием специальных исследований лексики, репрезентирующей лекарственные растения, но и отсутствием словаря флористической лексики кумыкского языка.

Целью данной работы является выявление и анализ принципов мотивации фармакофитонимов в тесной связи с концептуализацией и категоризацией мира носителями кумыкского языка.

Научная новизна статьи заключается в том, что в статье впервые выявлены принципы и характер номинации фармакофитонимов на материале кумыкского языка в тесной связи с концептуализацией мира носителями данного языка. 
Сбор эмпирического материала для исследования производился не только из лексикографических источников и художественных произведений кумыкских авторов, но и из материалов, собранных авторами во время экспедиций на места компактного проживания кумыков.

Лекарственные растения, как и все другие разновидности растений, обладают множеством признаков, из которых при номинации используется какой-то один из признаков. Каждая номинативная система «располагает определенным набором мотивировочных признаков номинации, детерминированных свойствами именуемых реалий» [Енгалычев 1989: 70]. Выбор того или иного специфического признака обусловлен социально-культурным опытом, национально-культурными традициями народа, окружающей средой, разного рода ассоциациями, связанными с теми или иными явлениями и т.д.

Одним из самых активных признаков, лежащих в основе мотивации растений, является цвет. Разные части растений могут обладать разными цветовыми признаками, которые ложатся в основу номинации.

По цвету листьев получило свое название репейник - къызылъяпыракъ и «душица обыкновенная» къарот, которые имеют сложную структуру цветообозначения: къызыл «красный» + япыракъ «лист» и къара «черный» + om «трава». Кумыкское название душицы къарот мотивировано цветом листьев лекарственного растения, которое используется для лечения болезней уха. Фармакофитоним къаразере «тмин» образован от слова къара «черный» и заимствованного из персидского языка слова зере «золото, золотой». Тмин как лекарственное растение еще в «первом тысячелетии н. э. широко использовался в медицине. Авиценна в своём «Каноне медицины» более 30 раз упоминает это растение» [Хапаев, Хапаева 2015: 239]. В кумыкском названии лекарственного растения къаразере «тмин» в результате метафорического осмысления отражены бесспорные полезные лечебные свойства черных зёрен тмина.

Цвет корней лежит в основе номинации лекарственного растения акътамур «пырей ползучий» (акъ «белый» + тамур «корень»), корни которого используются в качестве кровоочистительного средства. Цветообозначения лежат и в основе мотивировки фитонимов къаратамур (къара «черный» + тамур «корень») «чернокорень обыкновенный» и боявтамур (бояв «крашеный» + тамур «корень») «корень марены».

Номинация следующих растений произошло по цвету цветков растений: саричечек «зверобой»: сари «желтый» + чечек «цветок», акъчечек «ромашка»: акъ «белый + чечек «цветок», гёкчечек «1) василек 2) огуречная трава»: гёк «синий» + чечек «цветок».
В основе номинации растений может лежать не только качественные, но и количественные признаки, свойственные растениям. Так, именно количество листьев или лепестков и количество сочленений лежат в основе различительного признака следующих растений: мингяпыракъ (минг «тысяча» + япыракъ «растение») «тысячелистник», уьчкъулакъ (уьч «три» + къулакъ «ухо») «клевер горный», бешъяпыракъ (беш «пять» + япыракъ «лист») «сабельник болотный», юзьяпыракъ (юз «сто» + япыракъ «растение») «столетник». Названия растений данной семантической группы соответствуют структурному типу «числительное + существительное». Эти растения получили названия, прежде всего, по форме листьев или сочленений, вызывающих ассоциацию с их количеством.

В основе названий многих растений лежит соматический признак «внешний вид растения», например, форма листьев лекарственных растений. Названия фармакофитонимов, мотивированные внешней формой, можно разделить на следующие типы: а) названия, мотивированные внешней формой плодов растений: бурчагъот (бурчакъ «фасоль» + om «трава») «дикий клевер», аювчач (аюв «медведь» + чач «коса») «папоротник»; б) названия, мотивированные внешней формой листьев растений: бакъот (бакъа «лягушка» + от «трава») «подорожник», уьчкъулакъ (уьч «три» + къулакъ «ухо») «клевер», тюклот (тюклю «ворсистая» + от «трава») «ягель»; в) названия, мотивированные внешней формой цветков растений: оймакъчечек (оймакъ «наперсток» + чечек «цветок») «наперстянка», ташчечек (таш «камень» + чечек «цветок») «мох», инжичечек (инжи «жемчуг» + чечек «цветок») «ландыш».

К топологическим признакам относится место произрастания растений. По ассоциации с яблоком, которое растет на дереве названо растение ералма (ер «земля» + алма «яблоко») «земляное яблоко, топинамбур», где первая часть сложного слова указывает на место локализации растения. В некоторых диалектах это растение имеет название ерчита (ер «земля» + чита «морковь»). В этом случае местом локализации растения является земля по ассоциации с морковью. Земля как место локализации растения лежит в основе номинации слова ерсагъыз (ер «земля» + сагъыз «смола») «молочай», еркъоз (ер «земля»+ къоз «орех) «арахис».

Некоторые лекарственные растения растут только на склонах гор. Этот топологический признак места отразился в номинации ряда лекарственных растений. Дифференциальный топологический признак «место произрастания растения - горы» лежит в основе номинации фитонима тавмичари (букв. тав «гора» + мичари «кукурузный хлеб») «тмин», тавчай (тав «гора» + чай) «зверобой», тавманналакъ (тав «гора» + манналакъ «бутень») «бутень горный», тавсагъыз (тав «гора» + сагъыз «смола») «козелец», тавхурма (тав «гора» + хурма «хурма») «эбеновое дерево». 
Местом локализации ряда растений может быть не только земля, но и вода, так как многие лекарственные растения растут возле рек, болот и водоемов. Мотивирующим признаком номинации следующих фармакофитонимов является топологический признак «вода - место произрастания фитонима». Десмодиум гиранс - уникальный цветок, который получил свое название сувда бийийген «танцующий в воде» не только потому, что растет в воде, но и танцует, радуясь солнечным лучам.

Еще одно лекарственное растение, растущее в воде - сувкъоз (сув «вода» + къоз «орех») «водяной орех». Длинный тонкий стебель прошлогодними орехами прикрепляется ко дну водоема. «Растение вместе с прошлогодним плодом легко отрывается от грунта и может свободно плавать, пока заново не зацепится рогами плода с последующим укоренением» [Кулуев, Артюхин, Шевченко, Михайлова 2017: 103].

Фармакофитоним сувот (сув «вода» + om «трава») «ряса болотная» получила свое название по месту произрастания: стоячая вода, болото. К этой же подгруппе относятся и такие названия растений, как: сувсар «артишок», сувхалта (сув «вода» + халта «конский щавель») «горец перечный», сутлу халта «стебли молочая» (съедобные).

Таким образом, одним из универсальных онтологических категорий, обусловливающих процесс познания фармакофитонимов, является локус. Мотивирующий признак «локус» отражает природно-географический ландшафт места проживания носителей кумыкского языка. В роли детерминантов места локализации выступают лексемы тав «гора», ер «земля», сув «вода», агъач «лес», орман «лес», авлакъ «степь», къыр «поле». Например, ерчита (ер «земля» + чита «морковь») «топинамбур», авлакъхаркъа (авлакъ «поле» + харкъа «фасоль») «дикая фасоль» и др.

По способу произрастания, роста или распространения получили наименования чырмавукъ «вьюнок», къыркъбувун (досл. сорок сочленений) «хвощ», чалмюкот (чалмюк «парный» + от «трава») «череда».

Вкусовые качества плодов растений легли в основу мотивации следующих наименований растений: шекер чювюннюр «сахарная свекла», кампеткокан (конфетаслива) «ренклод колхозный», аччот (аччы «горькая» + оm «трава») «осот»; татыран (горький) «хрен», шекеркъамуш «сахарный тростник», аччы ювщан «горькая полынь».

Таким образом, в основе приведенных названий лекарственных растений лежит принцип номинации, оценивающий сладкий и горький вкусы фитонимов.

Номинация по способности растения выделять за- пах представлена в примерах ийисли оччам «укроп пахучий», ийисли ханс «тимьян ползучий», ийисли къазаякъ «марь вонючая», ийислот (ийисли «пахучая» + от «трава») «душица обыкновенная», атирчечек (атир «одеколон»+ чечек «цветок») «герань».

Непродуктивным является мотивировочный признак «этноним», который встречается в названиях следующих фармакофитонимов: ногъайюзюм (досл. ногайский виноград) «паслён», орус мая «русский хмель дрожжевой», орус оччам «русская петрушка», гьиндкъоз «индийский кокосовый орех».

Непродуктивными являются мотивировочные признаки «родственные отношения» и «характеристики человека», лежащие в основе номинаций следующих растений: а) оьгейаначечек (досл. мачеха-цветок) «матьи-мачеха», гелинчечек (досл. гелин «невеста» + чечек «цветок») «васильки рогатые»; б) адам тамур «адамов корень», уланъяпыракъ (улан «парень» + япыракъ «лист») «подорожник», къаракъыз (къара «черная» + къыз «девушка») «череда».

В кумыкском языке достаточно много названий лекарственных растений, созданных на основе метафорической номинации флоры, по разным моделям.

Модель «животное - растение» представлена как домашними, так и дикими животными. Мотивировочный признак не является случайным, а отражает характерные свойства реального животного мира, где жили и живут кумыки, он связан с популярностью растения в данном регионе и его лечебными свойствами. Данная модель используется в составе метафорических моделей, имеющих сложную структуру. В составе сложных фитонимов с зоонимическим компонентом чаще всего используются следующие названия домашних животных: къой «баран», am «лошадь», къозу «ягненок», теке «коза», которые в составе композит выступают в атрибутивной функции: къойот (къой «овца» + от «трава») «василек колючий»; къойтабан (къой «овца» + табан «копыто») «омела белая»; атбишлакъ (ат «лошадь + бишлакъ «сыр») «просверняк»; къозукъулакъ «щавель (досл.: ухо ягнёнок)»; текемюйюз (досл. коза рог) «череда» и др.

В метафорической модели «дикое животное - растение» чаще всего встречаются зоонимы къоян «заяц», тюлкю «лиса», донгуз «свинья», аюв «медведь», которые в составе композитных имен выступают в определительной функции. Например: къоянчечек (къоян «заяц» + чечек «цветок») «эспарцет», тюлкюкъуйрукъ (тюлкю «лиса»+ къуйрукъ «хвост») «чернобельник», аювчач (медвежья коса) «ковыль».

В составе метафорической модели «птица - растение» используются орнитонимы къуш «птица», тавукъ 
«курица», къаз «гусь», къарлыгъач «ласточка»: тавукъ ашамайгъан (тавукъ «курица» + ашамайгъан «не кушающий») «курослеп, къарлыгъачот (къарлыгъач «ласточка» + от «трава») «жабник», къазаякъ (къаз «гусь»+ аякъ «лапа») «пустырник пятилопастный». Все эти наименования представляют собой семантические дериваты со сложной структурой, то есть, композиты.

Фитонимы, получившие названия на основе функциональной мотивации, делятся на следующие подгруппы: а) названия, указывающие на лечебные свойства растений: ярот (яра «рана» + от «трава») «алтей», темиревот (темирев «лишай» + от «трава») «чистотел», яра ювшан (яра «рана» + ювшан «полынь») «дербенник», ётелбалам (букв. ётел «кашель» + балам «калина») «калина»; б) фитонимы, мотивационным признаком которых является «характерное действие»: сёнмесчечек (сёнмес «не угаснет» + чечек «цветок») «бессмертник», бурнун къанатагъан (досл. вызывающий кровотечение носа) «пырей ползучий», тавукъ къырагъан (тавукъ «курица», къырагъан «уничтожающий») «паслен черный»; в) фитонимы, получившие свои названия на основе признака «съедобности и несъедобности»: ашайгъан косук (букв. съедобный козлобородник) «козлобородник» (после цветения растения корень козлобородника становится несъедобным), гъарамчум (запретный, поганый кизил) «тис», ялгъан къычыткъан (досл. фальшивая крапива) «несъедобная крапива».

На основе этологической мотивации поведения волка получилось название фитонима бёрюгёз (бёрю «волк» + гёз «глаз») «паслен», ягоды которого ядовиты. Ягоды данного фитонима уподобляются волку.
Исламское представление о шайтанах связано с олицетворением нехороших качеств человека. В названиях растений лексема шайтан «черт» используется для обозначения колючих сорняков и несъедобных трав: шайтан харбуз (букв. шайтан «черт» + харбуз «арбуз») «каперсы колючие, каперсы», шайтан къимира (букв. шайтан + къимира «съедобное растение из семейства укропных»), шайтан таякъ (букв. шайтан + таякъ «палка») «чертополох».

Мотивировочный признак «функциональная предназначенность фитонима» лежит в основе следующих названий растений: одного из разновидностей синеголовника полевого - гёзтегенек (гёз «глаз» + тегенек «колючка») Сухой синеголовник полевой кумыки вешали у входа в дом, чтобы нечистая сила не смела шагнуть за порог дома.

Таким образом, в основе мотивировки названий фармакофитонимов кумыкского языка лежат самые разные признаки растений: цвет, внешний вид, локус, предназначенность и т.д. Самым частотным из названных типов мотивации фитонимов является мотивация по внешнему виду растения, которая отражает глубочайшие знания народа об окружающем растительном. Все это говорит о том, что народная медицина оставила глубокие следы в лексике кумыкского языка, на протяжении многих столетий, передавая из поколения в поколение, не только целебные свойства, но и названия лекарственных растений. Большинство лекарственных травянистых растений в исследуемом языке обладают легко восстанавливаемой прозрачной внутренней формой слова.

\section{ЛИТЕРАТУРА}

1. Gaciahmedov, N . Структурно-семантические типы и принципы номинации фитонимов в кумыкском языке // Tehlikedeki Diller Dergisi, 11 (18). — Aнкара, 2021. - C. 55-64.

2. Абдуллаева У.А. Агроботаническая лексика алходжакентского говора кумыкского языка: дис ...канд. филол. наук. — Махачкала, 2006. — 152 с.

3. Бамматов Б.Г., Гаджиахмедов Н.Э. Кумыкско-русский словарь. Магьачкъала: ИЯЛИ ДНЦ РАН, 2013. — 523 с.

4. Гаджиахмедов Н.Э., Абдуллаева А.А., Айбатырова М.А. Принципы номинации растений в кумыкском языке // Мир науки, культуры и образования, 3(82), 2020. - С. 336-339.

5. Гаджиахмедов Н.Э., Айбатырова М.А. Структурно-семантические типы фитонимов в кумыкском языке // Мир науки, культуры и образования, 3(82), 2020. - С. 333-336.

6. Енгалычев Н.А. Средства и способы номинации в русской естественнонаучной номенклатуре (на материале миконимов): дис... канд. фил. наук. Ташкент, 1989. - 192 c.

7. Исмаилова А.Х. Лексические особенности терминов флоры в современном кумыкском языке. Филологические науки. Вопросы теории и практики: в 3 ч. — Тамбов: Грамота, 2017; Ч. 3, № 5 (71). - С. $90-93$.

8. Исмаилова А.Х., Гаджиев Э.Н. К проблеме изучения фитонимической лексики в кумыкском языке // Филологические науки. Вопросы теории и практики. — Тамбов: Грамота, 2016. № 2(56): в 2-х ч. Ч. 2. - С. 91-94.

9. Крымханова А.Б., Гаджиахмедов Н.Э. Современные проблемы науки и образования. 2012; № 4. - С. 296 - 300.

10. Кубрякова Е.С. Роль словообразования в формировании языковой картины мира // Роль человеческого фактора в языке. Язык и картина мира. М.: Наука, 1988. - С. 141-172. 
11. Кулуев Б.Р., Артюхин А.Е., Шевченко А.М., Михайлова Е.В. Водяной орех плавающий TRAPA L.: биология, ареал распространения и исследование его изолированных популяций в озерах нуримановского района республики Башкортостан // Биомика, 2017, Том 9, № 2. — С. 101-118.

12. Хапаева Л.В. Когнитивные и прагматические стратегии именования единиц флоры (на материале карачаево-балкарского и русского языков): дис. ...канд. филол. наук. — Нальчик, 2016. - 173 с.

○ Гаджиахмедов Нурмагомед Эльдерханович (nur1@yandex.ru), Айбатырова Пахай Казбековна (aybat13@yandex.ru), Гаджиахмедова Аида Нурмагомедовна (ajka13@mail.ru).

Журнал «Современная наука: актуальные проблемы теории и практики»

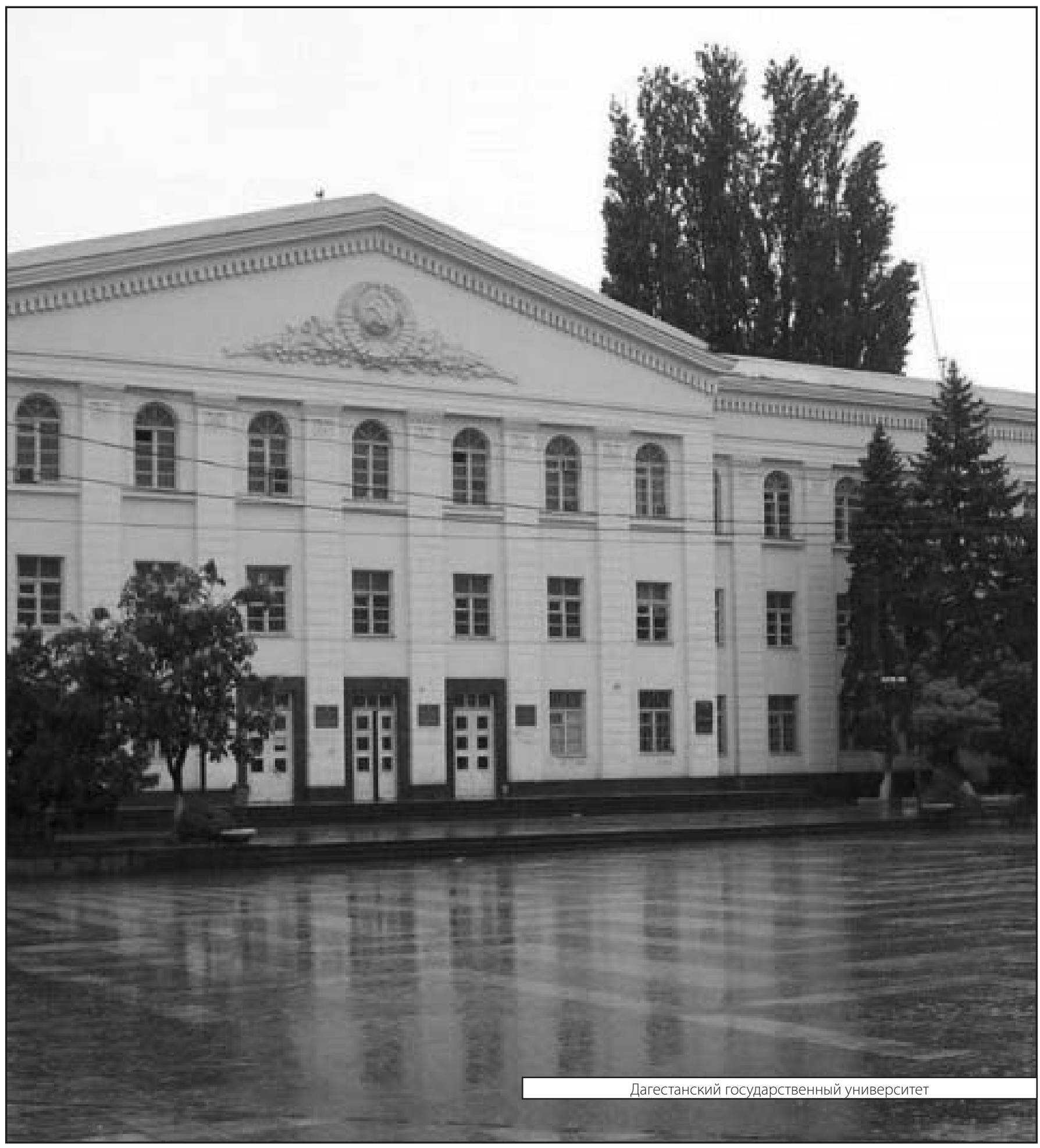

